\title{
Incomplete Eradication of Persistent Infection May Impede Union: Our Experience in Treating Fracture Non-Unions with Allogenic MSC
}

Ismail Hadisoebroto Dilogo ( $\square$ ismailortho@gmail.com )

Universitas Indonesia https://orcid.org/0000-0003-4060-2260

Alberto Lastiko Hanitya

Universitas Indonesia

Jeanne Adiwinata Pawitan

Universitas Indonesia

Isabella Kurnia Liem

Universitas Indonesia

Nyimas Diana Yulisa

Universitas Indonesia

Research article

Keywords: mesenchymal stem cells, fracture, non-union, infection

Posted Date: January 13th, 2020

DOI: https://doi.org/10.21203/rs.2.20713/v1

License: (c) (i) This work is licensed under a Creative Commons Attribution 4.0 International License. Read Full License 


\section{Abstract}

Introduction : Non-union remains a major clinical challenge for orthopaedic surgeons, as the treatments are associated with risks for complications, and sometimes multiple surgeries are required. Mesenchymal stem cells (MSCs) have been found to aid in osteogenesis and fracture healing; however, the number of studies on MSC application for treating non-unions is still sparse. We present a translational study of 8 subjects treated with MSC implantation, along with those considered as standard treatments in treating non-unions. To our knowledge, this is the most extensive clinical study on the use of MSCs to treat fracture non-unions.

Methods: We performed 20x10 6 units of MSC implantations derived from adipose tissue, bone marrow, and umbilical cord on subjects diagnosed with fracture non-union of the long bone, along with internal fixation and hydroxyapatite-calcium sulphate (HA-CaSO 4 ) pellets. We excluded pathological fractures, subjects with immunological deficiencies (type II diabetes mellitus, and HIV/AIDS), and subjects with a history of immunosuppressive therapies. All subjects were assessed using the Disabilities of the Arm, Shoulder, and Hand (DASH) or Lower Extremities Functional Scale (LEFS), and visual analog score (VAS). Serial radiological images were also assessed using Tiedeman and Lane-Sandhu scoring to determine union. Follow up assessments were performed every three months for at least 12 months or until clinical and radiological union was achieved.

Results: Four (50\%) out of eight subjects developed union in a median of five (3-12) months. There was a reduction of VAS, from a median of 1 (0-6) to 0 (0-4), and an increase in mean LEFS/DASH of $56.25 \pm 10.71$ to $65 \pm 22.72$. However, the infection was identified in $3(37.5 \%)$ subjects. Methicillin-resistant Staphylococcus aureus (MRSA) was identified in two (25\%) subjects, while one was infected with Escherichia coli . No other adverse events occurred during the follow-up period.

Conclusion: Allogenic MSC implantation can be used as a potential and safe therapy for fracture non-union. However, the presence of infection may interfere with bone healing; thus, thorough eradication of infection must be ensured to achieve fracture union. Further clinical studies are required to investigate the safety and efficacy of allogeneic MSC implantation.

\section{Introduction}

Treating non-unions remains an arduous task in orthopaedics and traumatology surgery. Previous studies discovered the overall relative risk of non-union in long bone fracture to range from $1.9-10 \%$, with observable peaks in young adults. ${ }^{1,2}$ Inadequate care of several factors may contribute to the diminution of bone healing, which includes mechanical, biological, and infection. 3,4 Among these, an infection may be present in up to $40 \%$ of non-union cases. ${ }^{4}$ Failure to address and treat these problems may lead to devastating outcomes for patients, such as permanent disability.

While there is no universal consensus on standardized diagnostic criteria and therapy to treat fracture non-unions, ${ }^{5-7}$ standard procedures include reconstructive surgery using bone grafts or synthetic granules to achieve union. However, outcomes from this procedure vary widely and can lead to a series of revision surgeries. ${ }^{2}$ Different bone grafts are used in cases where defects are present; these can range from autograft, allograft, or synthetics grafts. After ten years, graft failure is still observed in approximately $60 \%$ of cases, leading to recurring non-union. ${ }^{8}$

Fracture healing consists of several complicated processes from hematoma formation until bone remodeling, which includes mesenchymal stem cell (MSC) recruitment in the acute inflammatory phase. The recruited MSCs, which were hypothesized to be derived from the surrounding tissues, will aid in the bone synthesis and regulate bone remodeling and angiogenesis. ${ }^{8,9}$ Previous studies have found that bone marrow mesenchymal stem cell (BM-MSC) implantation has improved bone healing in patients with non-union and critical-sized bone defects. However, the obtainment of BM-MSC may expose donors to potential morbidities, such as sciatic nerve injury, hemorrhage, pain, and infection. ${ }^{10-13}$ Stem cells derived from umbilical cord and adipose tissue have attracted researchers as the accretion is not as invasive; therefore, may avert donors from the previously mentioned drawbacks. ${ }^{14,15}$ Adipose-derived stem cells (ADSCs) and umbilical cord mesenchymal stem cells (UC-MSCs) were shown to aid in osteogenesis and fracture healing as demonstrated in the previous studies. ${ }^{14-17}$

This study is aimed to investigate the efficacy of allogeneic MSC implantation, regardless of the origin, in treating non-union of the long bones. 


\section{Methods}

\section{Subject Selection}

This case series included subjects diagnosed with fracture non-union of the long bone, defined as a disturbance of bone growth after nine months or absence of the bridging callus in the first three months consecutively, in Cipto Mangunkusumo General Hospital (Jakarta, Indonesia) between 2014 and 2018. Subjects with long bone fracture non-union aged 0 to 55 years old were enrolled in this study. We excluded cases of non-union due to pathological fracture (e.g., primary or secondary bone malignancy), subjects with immunologic deficiencies (e.g., HIV/AIDS, type II diabetes mellitus, hepatitis), and subjects undergoing immunosuppressive therapy (e.g. chemotherapy, corticosteroid regimens).

\section{MSC Acquisition}

MSC used for implantation were derived from adipose tissue, bone marrow, and umbilical cord. All donors were screened for HIV, Hepatitis B, and Hepatitis C. BM-MSC was extracted from donors aged 19 to 30 without comorbidities (e.g., type II diabetes mellitus, cardiovascular diseases, autoimmune diseases). All donors are positioned on an operating table under local anesthesia. Aspiration needle is inserted $45^{\circ}$ into the iliac crest, and then the needle hub is removed and connected to a $20 \mathrm{ml}$ syringe filled with $1-2 \mathrm{ml}$ of $1,000 \mathrm{lU} / \mathrm{ml}$ heparin. The bone marrow is aspirated by pulling the syringe plunger backward rapidly. Several syringe rotations are made to retrieve aspirate in different sites. Next, the aspirate is transferred into a $50 \mathrm{ml}$ sterile polypropylene tube. Lastly, the aspiration needle is removed, and pressure is applied on the skin, followed by dressing of the wound. UC-MSC was obtained from elective cesarean sections from mothers with uncomplicated full term (37 - 42 weeks) pregnancy, and ADSC was obtained from adipose tissue residues from liposuction procedures. The MSCs attained were collected and stored in sterile containers filled with $0.9 \% \mathrm{NaCl}$ at $4^{\circ} \mathrm{C}$. Cells were processed within 8 hours following the corresponding procedure.

\section{Culture, Characterization, Cryopreservation, and Activation of MSC}

The obtained bone marrow, umbilical cord, or adipose tissue was processed in a Good Manufacturing Practices (GMP)standardized culture laboratory at the Stem Cell Medical Technology Integrated Medical Service Unit of Cipto Mangunkusumo General Hospital at the Faculty of Medicine at Universitas Indonesia (Jakarta, Indonesia). Processing was performed using the multiple harvest-explant methods as detailed by Pawitan et al. ${ }^{18}$. Cell culture was performed using the appropriate medium and subcultured until confluence was achieved, and then the cells can be harvested (approximately in $21-28$ days). Characterization is conducted using flow cytometry and cells are declared as MSC with CD105, CD90, and CD73 expression $\geq 95 \%$ with CD34 and CD45 expression $\leq 2 \%$. Cells from passages 3 to 6 were then implanted onto recipients with non-union. Part of the characterized MSC was then stored inside $-180^{\circ} \mathrm{C}$ nitrogen tanks for cryopreservation. Cryopreserved MSCs were activated and analyzed for its viability every three months.

\section{Intervention}

Each subject was given $20 \times 10^{6}$ units MSC and hydroxyapatite-calcium sulphate $\left(\mathrm{HA}-\mathrm{CaSO}_{4}\right)$ pellets (Bongros-HA, Bioalpha, Seongnam, Korea) per defect site. MSC was diluted in $10 \mathrm{cc}$ per $\mathrm{cm}^{3}$ defect conditioning medium, then transferred into a container filled with $\mathrm{HA}_{-}-\mathrm{CaSO}_{4}$. Each container was incubated for 5 minutes before implantation. $\mathrm{MSC}$ and $\mathrm{HA}-\mathrm{CaSO}_{4}$ components were then implanted into the non-union / defect site while installing bone fixation. After the soft tissue was sutured, the remaining serum was then injected into the defect surroundings using a $5 \mathrm{cc}$ syringe. For cases with infected non-unions, subjects were treated with gentamicin-loaded cement spacer on the fracture site before definitive fixation surgery. 
The clinical and radiological evaluation was performed every three months postoperatively until clinical and radiological union was achieved, or up to 12 months post-op. Clinical evaluation was performed using the Disabilities of the Arm, Shoulder, and Hand $(\mathrm{DASH})^{19}$ questionnaire for non-union in the upper extremities, and the Lower Extremities Functional Scale (LEFS) ${ }^{20}$ questionnaire for lower extremities. DASH scores ranges from 0 (most functional) to 80 (least functional); LEFS scores ranging from 0 (least functional) to 10 (most functional). All DASH and LEFS scores were translated into percentages for comparative purposes. Each subject's visual analog score (VAS) was assessed in every follow-up meeting as well.

Radiological results were assessed using Tiedeman ${ }^{21}$ (Table 1) and Lane-Sandhu ${ }^{22}$ (Table 2) scoring. The Tiedeman score is calculated by totaling the score in each aspect. A radiological union is considered achieved when Lane-Sandhu score is $\geq 2$ and Tiedeman score $\geq 6$.

\section{Results}

Of the eight subjects included in this study, four subjects achieved union, with the time of union ranging from two to 12 months. One subject requiring reimplantation during follow up: Subject 3 underwent three separate MSC implantations due to recurrent infections resulting in non-unions. (Fig. 1-8) Despite four reported cases of radiological non-unions, three subjects showed a slight improvement in functional activity and pain, as assessed using the the LEFS/DASH questionnaires and VAS score.

\section{Discussion}

Non-union remains a challenging problem for orthopaedic surgeons, as it delays recovery and often requires multiple follow-up procedures. Numerous methods of treatment, such as autologous bone graft and allograft bone chips, are available for this condition; however, they are often associated with drawbacks and high costs. ${ }^{23}$ In recent years, mesenchymal stem cell implantation has garnered interest worldwide due to its regenerative capacity.

Moreover, both preclinical and clinical studies have shown that MSC can aid in bone regeneration. ${ }^{15,24-27}$ The most common source of MSC is bone marrow; however, its isolation requires an invasive procedure, often causing pain and discomfort to the donors. Other accessible sources include adipose and umbilical cord tissue, which both obviate the need for invasive isolation as they are byproducts of liposuction and childbirth. In this study, we investigate the safety and efficacy of ADSCs and UC-MSCs for treating nonunion.

In this study, 5 (62.5\%) subjects developed union in 2-12 months. To our knowledge, this is the most extensive series of allogeneic MSCs in subjects with nonunion. Previously, we administered allogeneic UC-MSCs for infected non-union femoral shaft fracture with a $12 \mathrm{~cm}$ bone defect. ${ }^{15}$ There was a reduction of VAS, from a median of $1(0-6)$ to $0(0-4)$, and increase in mean LEFS/DASH of $56.25 \pm 10.71$ to $65 \pm 22.72$ in one year of follow-up. In an animal model, Qu et al. found that the administration of UC-MSCs resulted in disappearance of fracture line at eight weeks. ${ }^{28}$ Most subjects still have significant LLD following the procedure that may interfere with daily activities. However, the primary outcome of this study is to achieve union, while this issue can be managed with additional procedures following bone union, such as bone lengthening using the llizarov apparatus or lengthening and intramedullary nailing. Regardless the rarity of the occurrence, it should be noted that this procedure might expose the subjects to risks of complications, such as pain, infection, and failure of treatment. ${ }^{29-31}$

The mechanisms by which exogenous MSC implantation enhances fracture healing have been extensively studied. It was previously postulated that fracture healing occurs due to differentiation of transplanted cells; however, in non-unions without critical bone loss, the implanted MSCs largely act as cellular modulators, instead of directly differentiating, as the differentiation of transplanted MSC at the site was less efficient. ${ }^{15,32-34}$ Contrary to previously held beliefs, it is the release by MSCs of their secretome, an assemblage of paracrine factors (e.g. cytokines, growth factors, etc.), into the extracellular environment that plays the crucial role in fracture healing. ${ }^{34,35}$ Several cytokines contained in secretome include insulin-like growth factor-1 (IGF-1), vascular endothelial growth factor (VEGF), transforming growth factor- $\beta$ (TGF- $\beta$ ), and hepatocyte growth factor (HGF). These factors enhance migration and recruitment of osteoprogenitor cells (osteoblasts) to the implantation site and assists in 
upregulation of cell proliferation and differentiation. ${ }^{15,35}$ Besides, these factors also aid in angiogenesis, in order to fulfill oxygen and nutritional requirements during fracture healing. ${ }^{35}$

In comparison from other types of stem cells, MSC poses a shallow risk when implanted. Implantation of exogenous MSC, whether differentiated or undifferentiated, does not cause alloreactive lymphocyte proliferation and does not elicit further immune responses. This suggests that MSC is a safe and potential alternative therapy for treating nonunion.

Contact between fracture fragments should be established to assist bridging between the two fragments. In several cases in our study, we utilized double-plating to ensure contact, alignment, and mechanical stability of the fracture site. In a report by Steinberg et al., double-plating may help in aiding mechanical stability in femoral distal or supracondylar fractures by reducing lever arm and load on the fracture size, which improves fracture stabilization and prevents implant loosening. ${ }^{36,37}$ We also performed dynamization on subject Bub (case no. 4) by removing the distal screw in the tibia after intramedullary (IM) nailing. Dynamization may promote fracture healing and can be proposed as the primary treatment in non-union cases. ${ }^{6,38,39}$ However, it should be taken into consideration that the use of intramedullary reaming and nailing, in particular, affects the microvasculature of the bone. As demonstrated in an animal study, bone reaming may destroy the endosteum microvasculature, which is usually followed with vasculature hypertrophy of the periosteum. ${ }^{40}$

Status of infection may affect bone healing. Changes in the biological environment caused by open fractures may alter the healing process and lead to further septic complications. ${ }^{41}$ Infection, in coexistence with metal fixtures, may cause osteolysis, loosening, and mechanical failure, eventually making union harder to achieve. ${ }^{42,43}$ Therefore, eradication of infection must be assured to establish bone union. Radical resection should be performed as needed, debriding all infected and potentially infected non-viable tissue. ${ }^{44}$ One approach to aid eradication of infection is by performing the Masquelet procedure, which includes local antibiotic delivery as its first step. Subject compliance is another external aspect to be taken into consideration, as antibiotic therapy may be prolonged in this condition.

We observed several complications during our study, in which three experienced infections during follow up. Tissue culture examination revealed two methicillin-resistant Staphylococcus aureus infection. Both subjects were referred to the tropical diseases and infection specialists in our hospital and treated with appropriate antibiotics according to the sensitivity test. Subject 7 (Tas) was administered oral rifampicin and trimethoprim/sulfamethoxazole and underwent sequestrectomy, debridement, and antibiotic-loaded bone cement application. Subject MYu (case no. 2) was given oral trimethoprim/sulfamethoxazole. Multiple MSC implantations with Masquelet procedure stage II were performed on Subject 3 (Suy); however, radiological union has been achieved. The subject complained of mild to moderate pain during follow up (VAS: 3-5) and wound dehiscence. Culture examination revealed Escherichia coli infection, and the subject was treated with oral trimethoprim/sulfamethoxazole according to the sensitivity test. The subject was planned for another debridement and another round of the Masquelet procedure.

Currently, the application of bone morphogenetic protein (BMP) as an osteoinductive agent in treatment is being investigated. It is hypothesized that the addition of recombinant human bone morphogenetic protein 2 (rhBMP2) may assist proliferation and differentiation of MSC, while recombinant human bone morphogenetic protein 7 (rhBMP7) may support osteoblast differentiation. ${ }^{45}$ Unfortunately, results of multiple studies regarding the use of BMP remain inconclusive. ${ }^{46,47}$ We are further exploring the possibility of incorporating BMP and MSC treatment.

\section{Conclusion}

Allogeneic mesenchymal stem cells could be used as a potential therapy for fracture nonunions. However, the presence of infection may interfere with bone healing; thus, thorough eradication of infection must be ensured to achieve fracture union. However, further more extensive clinical studies are required to investigate their safety and efficacy.

\section{Abbreviations}

AIDS

acquired immunodeficiency syndrome 
ADSC

adipose-derived stem cells

BM-MSC

bone marrow mesenchymal stem cells

BMP

bone morphogenetic protein

DASH

the Disabilities of the Arm, Shoulder, and Hand

GMP

Good Manufacturing Practices

$\mathrm{HA}-\mathrm{CaSO}_{4}$

hydroxyapatite-calcium sulphate

HGF

hepatocyte growth factor

HIV

human immunodeficiency virus

IGF-1

insulin-like growth factor-1

IM

intramedullary

LEFS

Lower Extremities Functional Scale

LLD

leg length discrepancy

MSC

mesenchymal stem cells

MRSA

methicillin-resistant Staphylococcus aureus

rhBMP2

recombinant human bone morphogenetic protein 2

rhBMP7

recombinant human bone morphogenetic protein 7

TGF- $\beta$

transforming growth factor- $\beta$

UC-MSC

umbilical cord mesenchymal stem cells

VAS

visual analogue score

VEGF

vascular endothelial growth factor

\section{Declarations}

\section{Ethical Approval and Consent to Participate}

This study has undergone ethical review and received approval from the Health Research Ethics Committee at Cipto Mangunkusumo General Hospital - Faculty of Medicine, Universitas Indonesia, reference no. 165/H2.F1/ETIK/2014. The protocol has been registered in ClinicalTrials.gov Protocols Registration and Results System, registration no. NCT02307435.

All patients have signed written consents to participate in this study. 


\section{Consent for Publication}

All patients have signed written consents for their clinical information to be published in this study.

\section{Availability of Data and Materials}

The datasets used and/or analysed during the current study are available from the corresponding author on reasonable request.

\section{Competing Interests}

All authors declared no conflict of interests.

\section{Funding}

This study has been funded by Lembaga Pengelola Dana Pendidikan, Ministry of Finance of the Republic of Indonesia, RISPRO LPDP Grant no. PRJ-22/LPDP/2018.

\section{Authors' Contributions}

IHD constructed the concepts of this research, performed the operation, and performed the data analysis.

ALH collected the data, performed the data analysis, and wrote the article.

JAP led the manufacturing of MSC used in this study, performed the data analysis, and reviewed the article.

IKL led the manufacturing of MSC used in this study, performed the data analysis, and reviewed the article.

NDY analysed and interpreted the radiological results.

All authors have read the final version of this article and approved for publication.

\section{Acknowledgements}

We would like to acknowledge the help from the staffs of Stem Cell Medical Technology Integrated Medical Service Unit, Cipto Mangunkusumo General Hospital - Faculty of Medicine, Universitas Indonesia and Stem Cell and Tissue Engineering Research Center, IMERI - Faculty of Medicine, Universitas Indonesia that have assisted in the administration and manufacturing of our stem cell products.

\section{References}

1. Mills LA, Aitken SA, Simpson AHRW. The risk of non-union per fracture: current myths and revised figures from a population of over 4 million adults. Acta Orthop. 2017;88(4):434-439. doi:10.1080/17453674.2017.1321351

2. Bennett PM, Stewart SK, Dretzke J, Bem D, Penn-Barwell JG. Preclinical therapies to prevent or treat fracture non-union: A systematic review. Cheungpasitporn W, ed. PLoS One. 2018;13(8):e0201077. doi:10.1371/journal.pone.0201077 
3. Panteli M, Pountos I, Jones E, Giannoudis P V. Biological and molecular profile of fracture non-union tissue: current insights. $J$ Cell Mol Med. 2015;19(4):685-713. doi:10.1111/jcmm.12532

4. Simpson AHRW, Tsang STJ. Non-union after plate fixation. Injury. 2018;49 Suppl 1:S78-S82. doi:10.1016/S00201383(18)30309-7

5. Ozkan S, Nolte PA, van den Bekerom MPJ, Bloemers FW. Diagnosis and management of long-bone nonunions: a nationwide survey. Eur J Trauma Emerg Surg. January 2018. doi:10.1007/s00068-018-0905-z

6. Bhandari M, Fong K, Sprague S, Williams D, Petrisor B. Variability in the definition and perceived causes of delayed unions and nonunions: a cross-sectional, multinational survey of orthopaedic surgeons. J Bone Joint Surg Am. 2012;94(15):e1091-6. doi:10.2106/JBJS.K.01344

7. Calori GM, Mazza EL, Mazzola S, et al. Non-unions. Clin Cases Miner Bone Metab. 2017;14(2):186-188. doi:10.11138/ccmbm/2017.14.1.186

8. Perez JR, Kouroupis D, Li DJ, Best TM, Kaplan L, Correa D. Tissue Engineering and Cell-Based Therapies for Fractures and Bone Defects. Front Bioeng Biotechnol. 2018;6:105. doi:10.3389/fbioe.2018.00105

9. Marsell R, Einhorn TA. THE BIOLOGY OF FRACTURE HEALING. Injury. 2011;42(6):551-555. doi:10.1016/j.injury.2011.03.031

10. Zhang $H$, Xue $F$, Jun Xiao H. Ilizarov method in combination with autologous mesenchymal stem cells from iliac crest shows improved outcome in tibial non-union. Saudi J Biol Sci. 2018;25(4):819-825. doi:10.1016/j.sjbs.2016.11.001

11. Imam MA, Holton J, Ernstbrunner $L$, et al. A systematic review of the clinical applications and complications of bone marrow aspirate concentrate in management of bone defects and nonunions. Int Orthop. 2017;41(11):2213-2220. doi:10.1007/s00264-017-3597-9

12. Wittig $\mathrm{O}$, Romano $\mathrm{E}$, Gonzalez $\mathrm{C}$, et al. A method of treatment for nonunion after fractures using mesenchymal stromal cells loaded on collagen microspheres and incorporated into platelet-rich plasma clots. Int Orthop. 2016;40(5):1033-1038. doi:10.1007/s00264-016-3130-6

13. Watson L, Elliman SJ, Coleman CM. From isolation to implantation: a concise review of mesenchymal stem cell therapy in bone fracture repair. Stem Cell Res Ther. 2014;5(2):51. doi:10.1186/scrt439

14. Ho-Shui-Ling A, Bolander J, Rustom LE, Johnson AW, Luyten FP, Picart C. Bone regeneration strategies: Engineered scaffolds, bioactive molecules and stem cells current stage and future perspectives. Biomaterials. 2018;180:143-162. doi:10.1016/j.biomaterials.2018.07.017

15. Dilogo IH, Primaputra MRA, Pawitan JA, Liem IK. Modified Masquelet technique using allogeneic umbilical cord-derived mesenchymal stem cells for infected non-union femoral shaft fracture with a $12 \mathrm{~cm}$ bone defect: A case report. Int $J$ Surg Case Rep. 2017;34:11-16. doi:10.1016/j.ijscr.2017.03.002

16. Veriter S, Andre W, Aouassar N, et al. Human Adipose-Derived Mesenchymal Stem Cells in Cell Therapy: Safety and Feasibility in Different "Hospital Exemption" Clinical Applications. PLoS One. 2015;10(10):e0139566. doi:10.1371/journal.pone.0139566

17. Tawonsawatruk T, West CC, Murray IR, Soo C, Peault B, Simpson AHRW. Adipose derived pericytes rescue fractures from a failure of healing-non-union. Sci Rep. 2016;6:22779. doi:10.1038/srep22779

18. Pawitan JA, Liem IK, Budiyanti E, et al. Umbilical Cord Derived Stem Cell Culture: Multiple-Harvest Explant Method. Int J PharmTech Res. 2014;6(4):1202-1208.

19. Hudak PL, Amadio PC, Bombardier C. Development of an upper extremity outcome measure: the DASH (disabilities of the arm, shoulder and hand) [corrected]. The Upper Extremity Collaborative Group (UECG). Am J Ind Med. 1996;29(6):602-608. doi:10.1002/(SICI)1097-0274(199606)29:6<602::AID-AJIM4>3.0.CO;2-L

20. Binkley JM, Stratford PW, Lott SA, Riddle DL. The Lower Extremity Functional Scale (LEFS): scale development, measurement properties, and clinical application. North American Orthopaedic Rehabilitation Research Network. Phys Ther. 1999;79(4):371383.

21. Tiedeman JJ, Lippiello L, Connolly JF, Strates BS. Quantitative roentgenographic densitometry for assessing fracture healing. Clin Orthop Relat Res. 1990;(253):279-286.

22. Lane JM, Sandhu HS. Current approaches to experimental bone grafting. Orthop Clin North Am. 1987;18(2):213-225. 
23. Kadhim M, Holmes L, Gesheff MG, Conway JD. Treatment Options for Nonunion with Segmental Bone Defects: Systematic Review and Quantitative Evidence Synthesis. J Orthop Trauma. 2017. doi:10.1097/BOT.0000000000000700

24. Fayaz HC, Giannoudis P V., Vrahas MS, et al. The role of stem cells in fracture healing and nonunion. Int Orthop. 2011;35(11):1587-1597. doi:10.1007/s00264-011-1338-z

25. Magnani M, Racano C, Abati CN, Granchi D, De Vescovi V, Stilli S. Use of MSC in the Treatment of the Congenital Pseudoarthrosis in Children. Surg Sci. 2014;5:555-561. doi:10.4236/ss.2014.512085

26. Dilogo IH, Kamal AF, Gunawan B, Rawung RV. Autologous mesenchymal stem cell (MSCs) transplantation for critical-sized bone defect following a wide excision of osteofibrous dysplasia. Int J Surg Case Rep. 2015;17:106-111. doi:10.1016/j.ijscr.2015.10.040

27. Dilogo IH, Mujadid F, Nurhayati RW, Kurniawan A. Evaluation of bone marrow-derived mesenchymal stem cell quality from patients with congenital pseudoarthrosis of the tibia. J Orthop Surg Res. 2018;13(1):266. doi:10.1186/s13018-018-0977-9

28. Qu Z, Guo S, Fang G, Cui Z, Liu Y. AKT Pathway Affects Bone Regeneration in Nonunion Treated with Umbilical Cord-Derived Mesenchymal Stem Cells. Cell Biochem Biophys. 2015. doi:10.1007/s12013-014-0378-6

29. Abdelkhalek M, El-Alfy B, Ali AM. Ilizarov bone transport versus fibular graft for reconstruction of tibial bone defects in children. J Pediatr Orthop B. 2016;25(6):556-560. doi:10.1097/BPB.0000000000000334

30. Xu W. Comparison of Intramedullary Nail Versus Conventional Ilizarov Method for Lower Limb Lengthening: A Systematic Review and Meta-Analysis. Orthop Surg. 2017;9(2):159-166. doi:10.1111/os.12330

31. Bernstein M. Practical Aspects of Posttrauma Reconstruction With an Intramedullary Lengthening Nail. J Orthop Trauma. 2017;31:S20-S24. doi:10.1097/BOT.0000000000000845

32. Berebichez-Fridman R, Gomez-Garcia R, Granados-Montiel J, et al. The Holy Grail of Orthopedic Surgery: Mesenchymal Stem Cells-Their Current Uses and Potential Applications. Stem Cells Int. 2017;2017:2638305. doi:10.1155/2017/2638305

33. Chen L, Tredget EE, Wu PYG, Wu Y. Paracrine factors of mesenchymal stem cells recruit macrophages and endothelial lineage cells and enhance wound healing. PLOS One. 2008;3(4):e1886. doi:10.1371/journal.pone.0001886

34. Lai RC, Chen TS, Lim SK. Mesenchymal stem cell exosome: a novel stem cell-based therapy for cardiovascular disease. Regen Med. 2011;6(4):481-492. doi:10.2217/rme.11.35

35. Katagiri W, Osugi M, Kawai T, Hibi H. First-in-human study and clinical case reports of the alveolar bone regeneration with the secretome from human mesenchymal stem cells. Head Face Med. 2016;12:5. doi:10.1186/s13005-016-0101-5

36. Steinberg EL, Elis J, Steinberg Y, Salai M, Ben-Tov T. A double-plating approach to distal femur fracture: A clinical study. Injury. 2017;48(10):2260-2265. doi:10.1016/j.injury.2017.07.025

37. Zhang W, Li J, Zhang H, et al. Biomechanical assessment of single LISS versus double-plate osteosynthesis in the AO type 33C2 fractures: A finite element analysis. Injury. 2018;49(12):2142-2146. doi:10.1016/j.injury.2018.10.011

38. Vaughn J, Gotha H, Cohen E, et al. Nail Dynamization for Delayed Union and Nonunion in Femur and Tibia Fractures. Orthopedics. 2016;39(6):e1117-e1123. doi:10.3928/01477447-20160819-01

39. Perumal R, Shankar V, Basha R, Jayaramaraju D, Rajasekaran S. Is nail dynamization beneficial after twelve weeks - An analysis of 37 cases. J Clin Orthop trauma. 2018;9(4):322-326. doi:10.1016/j.jcot.2017.12.007

40. Greksa F, Toth K, Boros M, Szabo A. Periosteal microvascular reorganization after tibial reaming and intramedullary nailing in rats. J Orthop Sci. 2012;17(4):477-483. doi:10.1007/s00776-012-0222-z

41. Stella M, Santolini E, Autuori A, Felli L, Santolini F. Masquelet technique to treat a septic nonunion after nailing of a femoral open fracture. Injury. 2018;49 Suppl 4:S29-S33. doi:10.1016/j.injury.2018.11.017

42. Killington K, Mafi R, Mafi P, Khan W. A Systematic Review Of Clinical Studies Investigating Mesenchymal Stem Cells For Fracture Non-Union And Bone Defects. Vol 12.; 2017. doi:10.2174/1574888X12666170915121137

43. Mills L, Tsang J, Hopper G, Keenan G, Simpson AHRW. The multifactorial aetiology of fracture nonunion and the importance of searching for latent infection. Bone Joint Res. 2016;5(10):512-519. doi:10.1302/2046-3758.510.BJR-2016-0138

44. Pace F, Randelli F, Ayeni OR, Pace A. Debridement, internal fixation and staged autogenous bone graft for the management of infected femoral non-union. Injury. 2018;49 Suppl 4:S48-S57. doi:10.1016/j.injury.2018.11.018 
45. Pannier S. Congenital pseudarthrosis of the tibia. Orthop Traumatol Surg Res. 2011;97(7):750-761.

doi:10.1016/j.otsr.2011.09.001

46. Shah H, Joseph B, Nair BVS, et al. What Factors Influence Union and Refracture of Congenital Pseudarthrosis of the Tibia? A Multicenter Long-term Study. J Pediatr Orthop. 2018;38(6):e332-e337. doi:10.1097/BP0.0000000000001172

47. Kesireddy N, Kheireldin RK, Lu A, Cooper J, Liu J, Ebraheim NA. Current treatment of congenital pseudarthrosis of the tibia: a systematic review and meta-analysis. J Pediatr Orthop B. 2018;27(6):541-550. doi:10.1097/BPB.0000000000000524

\section{Tables}

Table 1. Lane-Sandhu ${ }^{22}$ radiographic scoring

\begin{tabular}{cl}
\hline Score & \multicolumn{1}{c}{ Description } \\
\hline 0 & No callus \\
1 & Minimal callus formation \\
2 & Callus evident and beginning of the osseous formation \\
3 & Callus evident and fracture line almost obliterated \\
4 & Complete union with complete remodeling \\
\hline
\end{tabular}

Table 2. Tiedeman ${ }^{21}$ radiographic scoring

\begin{tabular}{cl}
\hline Score & \multicolumn{1}{c}{ Description } \\
\hline Bone formation \\
0 & No bone formation \\
1 & $25 \%$ of defect \\
2 & $50 \%$ of defect \\
3 & $75 \%$ of defect \\
4 & $100 \%$ of defect \\
& \\
Union & \\
0 & Intact fracture line \\
2 & Partial fracture line \\
4 & Absence of fracture line \\
& \\
Remodeling & No remodeling \\
1 & Remodeling on 1 side of the cortex \\
4 & Remodeling on both side of cortices \\
\hline
\end{tabular}

Table 3. Results 


\begin{tabular}{|c|c|c|c|c|c|c|c|c|c|c|c|c|c|c|}
\hline \multirow[t]{2}{*}{ No } & \multirow[t]{2}{*}{ Patient } & \multirow[t]{2}{*}{ Sex } & \multirow[t]{2}{*}{ Age } & \multirow[t]{2}{*}{ Diagnosis } & \multirow[t]{2}{*}{ Procedure } & \multirow{2}{*}{$\begin{array}{c}\text { MSC } \\
\text { Source }\end{array}$} & \multirow{2}{*}{$\begin{array}{l}\text { Time } \\
\text { to } \\
\text { Union }\end{array}$} & \multicolumn{2}{|c|}{ VAS } & \multicolumn{2}{|c|}{ LLD } & \multicolumn{2}{|c|}{ LEFS / DASH } & \multirow{2}{*}{$\begin{array}{l}\text { Follow } \\
\text { Up } \\
\text { Period }\end{array}$} \\
\hline & & & & & & & & Initial & $\begin{array}{c}\text { Follow } \\
\text { Up }\end{array}$ & Initial & $\begin{array}{c}\text { Follow } \\
\text { Up }\end{array}$ & Initial & $\begin{array}{c}\text { Follow } \\
\text { Up }\end{array}$ & \\
\hline 1 & SMa & $\mathrm{F}$ & 54 & $\begin{array}{l}\text { NU, right } \\
\text { humerus } \\
\text { (Previous } \\
\text { ORIF P/S) }\end{array}$ & $\begin{array}{l}\text { ORIF } \\
\text { reconstruction } \\
\text { with double } \\
\text { plate and } \\
\text { bone } \\
\text { reconstruction }\end{array}$ & UC & $\begin{array}{l}6 \\
\text { months }\end{array}$ & 6 & 0 & $\mathrm{n} / \mathrm{a}$ & $\mathrm{n} / \mathrm{a}$ & $\begin{array}{c}68.7 \\
\%\end{array}$ & $\begin{array}{c}12.96 \\
\%\end{array}$ & $\begin{array}{c}16 \\
\text { months }\end{array}$ \\
\hline 2 & $\mathrm{MYu}$ & M & 51 & $\begin{array}{l}\text { Infected NU, } \\
\text { right proximal } \\
\text { tibia } \\
\text { (Previous } \\
\text { ORIF P/S) }\end{array}$ & $\begin{array}{l}\text { ORIF P/S with } \\
\text { double plate }\end{array}$ & $\mathrm{AD}$ & - & 0 & 3 & $2 \mathrm{~cm}$ & $2 \mathrm{~cm}$ & $\begin{array}{c}61.25 \\
\%\end{array}$ & $\begin{array}{c}48.75 \\
\%\end{array}$ & $\begin{array}{c}12 \\
\text { months }\end{array}$ \\
\hline 3 & $\begin{array}{l}\text { Suy* } \\
\text { (3) }\end{array}$ & $\mathrm{M}$ & 49 & $\begin{array}{l}\text { Infected NU, } \\
\text { right } \\
\text { supracondylar } \\
\text { femur } \\
\text { (Previous 7x } \\
\text { ORIF P/S) }\end{array}$ & $\begin{array}{l}\text { Masquelet } \\
\text { procedure, } \\
\text { ORIF P/S }\end{array}$ & $\begin{array}{l}\text { 1. } \mathrm{AD} \\
\text { 2. } \mathrm{BM} \\
\text { 3. } \mathrm{UC}\end{array}$ & - & 3 & 3 & $2 \mathrm{~cm}$ & $2 \mathrm{~cm}$ & $\begin{array}{c}41.25 \\
\%\end{array}$ & $50 \%$ & $\begin{array}{c}36 \\
\text { months }\end{array}$ \\
\hline 4 & ESu & M & 61 & $\begin{array}{l}\text { NU, left } \\
\text { femoral shaft } \\
\text { (Previous } \\
\text { ORIF P/S and } \\
\text { IM nail) }\end{array}$ & $\begin{array}{l}\text { ORIF P/S, } \\
\text { bone grafting }\end{array}$ & UC & - & 3 & 0 & $1 \mathrm{~cm}$ & $1 \mathrm{~cm}$ & $\begin{array}{c}36.25 \\
\%\end{array}$ & $\begin{array}{c}73.75 \\
\%\end{array}$ & $\begin{array}{c}12 \\
\text { months }\end{array}$ \\
\hline 5 & Bub & M & 37 & $\begin{array}{l}\text { NU, left tibia } \\
\text { (Previous IM } \\
\text { nail) }\end{array}$ & $\begin{array}{l}\text { IM nail, } \\
\text { dynamization } \\
\text { / distal screw } \\
\text { removal }\end{array}$ & UC & $\begin{array}{l}3 \\
\text { months }\end{array}$ & 2 & 0 & $2 \mathrm{~cm}$ & $2 \mathrm{~cm}$ & $55 \%$ & $80 \%$ & $\begin{array}{c}23 \\
\text { months }\end{array}$ \\
\hline 6 & Sut & M & 20 & $\begin{array}{l}\text { Atrophic NU, } \\
\text { right proximal } \\
\text { femur } \\
\text { (Previous } 2 x \\
\text { ORIF P/S) }\end{array}$ & ORIF P/S & UC & $\begin{array}{l}12 \\
\text { months }\end{array}$ & 0 & 0 & $\begin{array}{l}12 \\
\mathrm{~cm}\end{array}$ & $8 \mathrm{~cm}$ & $\begin{array}{c}51.25 \\
\%\end{array}$ & $82.5 \%$ & $\begin{array}{c}15 \\
\text { months }\end{array}$ \\
\hline 7 & Tas & M & 63 & $\begin{array}{l}\text { Infected NU, } \\
\text { left femoral } \\
\text { shaft } \\
\text { (Previous } \\
\text { ORIF P/S) }\end{array}$ & $\begin{array}{l}\text { IM nailing, } \\
\text { bone cement }\end{array}$ & UC & - & 0 & 4 & $9 \mathrm{~cm}$ & $7 \mathrm{~cm}$ & $60 \%$ & $\begin{array}{c}61.25 \\
\%\end{array}$ & $\begin{array}{c}14 \\
\text { months }\end{array}$ \\
\hline 8 & $\mathrm{JNe}$ & M & 23 & $\begin{array}{l}\text { NU, left tibia } \\
\text { (Previous IM } \\
\text { nail, ORIF } \\
\text { P/S, and bone } \\
\text { grafting) }\end{array}$ & $\begin{array}{l}\text { ORIF P/S, } \\
\text { double plate }\end{array}$ & UC & $\begin{array}{l}4 \\
\text { months }\end{array}$ & 0 & 0 & $6 \mathrm{~cm}$ & $6 \mathrm{~cm}$ & $\begin{array}{c}57.5 \\
\%\end{array}$ & $\begin{array}{c}68.75 \\
\%\end{array}$ & $\begin{array}{c}12 \\
\text { months }\end{array}$ \\
\hline
\end{tabular}




\begin{tabular}{lc}
\hline \multicolumn{1}{c}{ Complications } & $\mathrm{n}$ \\
\hline Number of subjects & 8 \\
& \\
Radiological non-union & 4 \\
Infection & 3 \\
$\quad$ Methicillin resistant Staphylococcus aureus & 2 \\
Escherichia coli & 1 \\
& \\
Follow up surgery & \\
MSC reimplantation & 2 \\
\hline
\end{tabular}

\section{Figures}

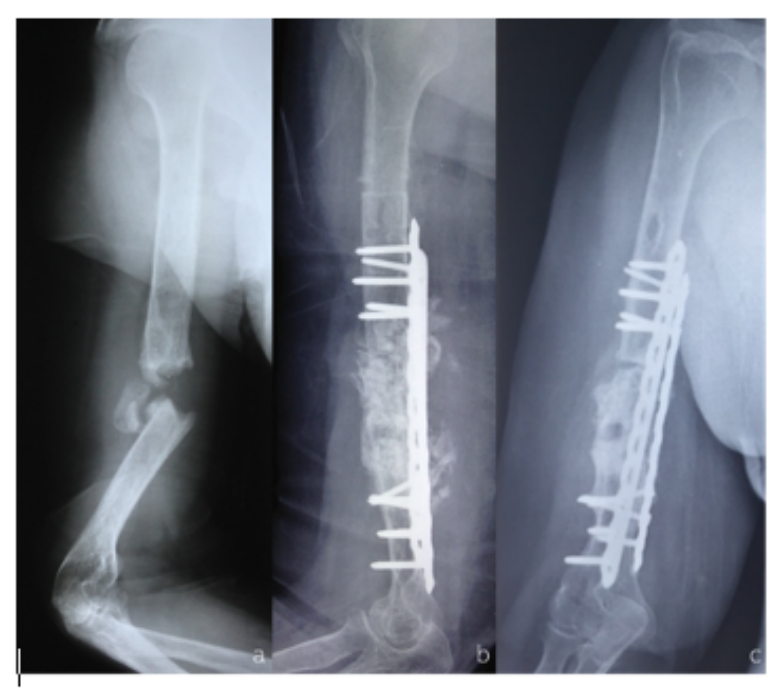

\section{Figure 1}

Radiograph of patient SMa (a) Pre-implantation; (b) Post implantation; (c) 12 months post implantation.

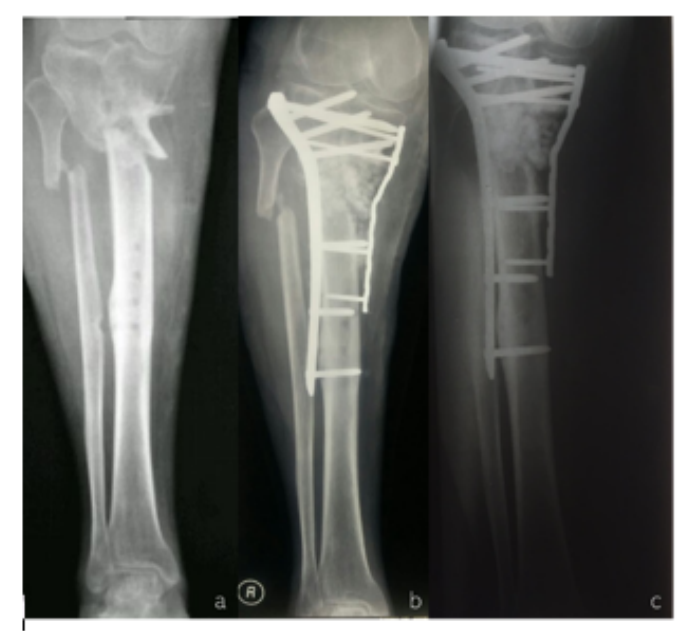

Figure 2 
Radiograph of patient MYu (a) Pre-implantation; (b) Post implantation; (c) 6 months post implantation.

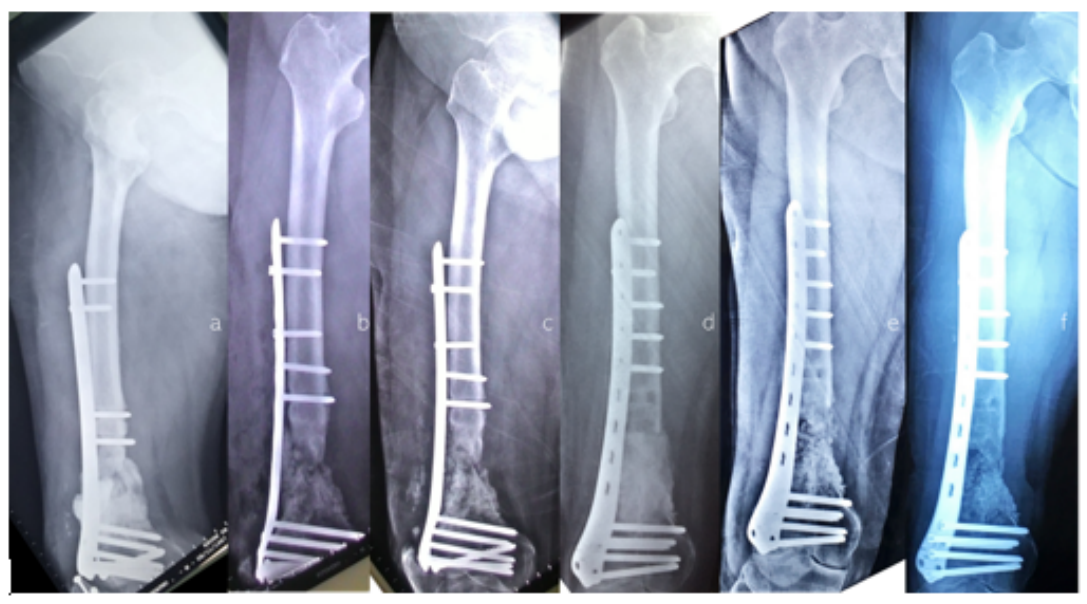

\section{Figure 3}

Radiograph of patient Suy (a) Pre ADSC implantation; (b) 10 months post ADSC implantation; (c) Immediately post BM-MSC implantation; (d) 8 months post BM-MSC implantation; (e) Immediately post UC-MSC implantation; (f) 12 months post UC-MSC implantation.

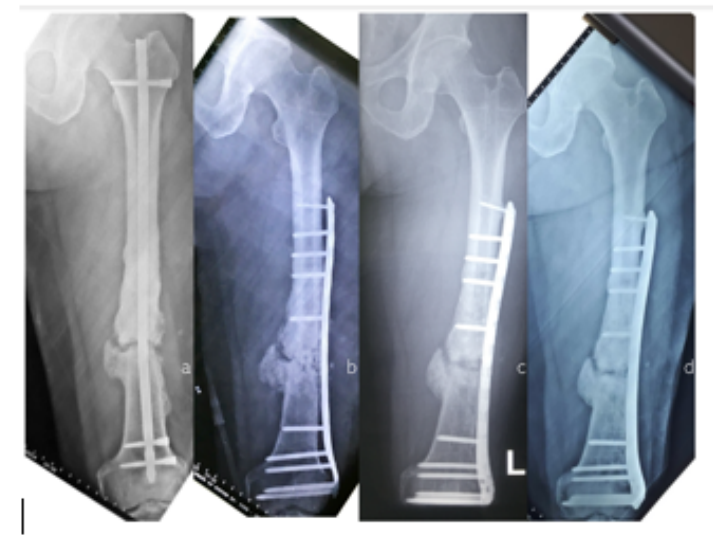

\section{Figure 4}

Radiograph of patient ESu (a) Pre-implantation; (b) Post implantation; (c) 7 months post implantation; (d) 12 months post implantation.

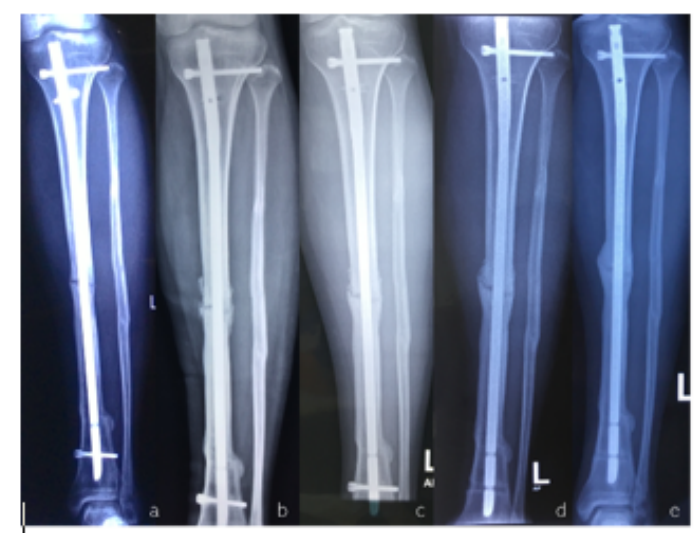

\section{Figure 5}


Radiograph of patient Bub (a) Pre-implantation; (b) Post implantation; (c) 6 months post implantation; (d) 14 months post implantation and distal screw removal; (e) 23 months post implantation

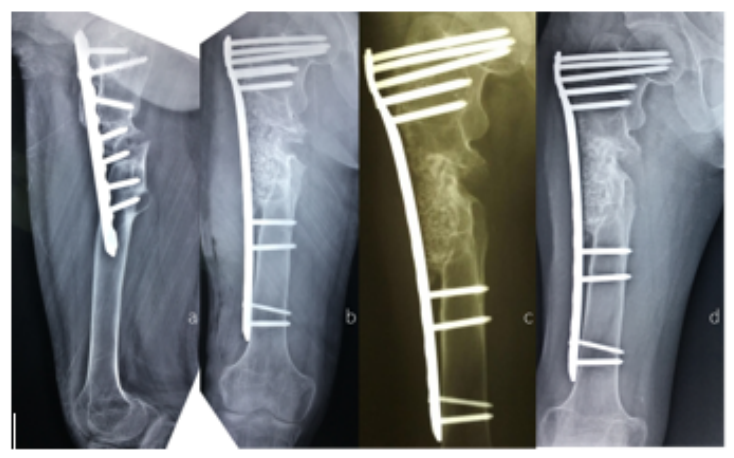

\section{Figure 6}

Radiograph of patient Sut (a) Pre-implantation; (b) Post implantation; (c) 6 months post implantation; (d) 12 months post implantation.

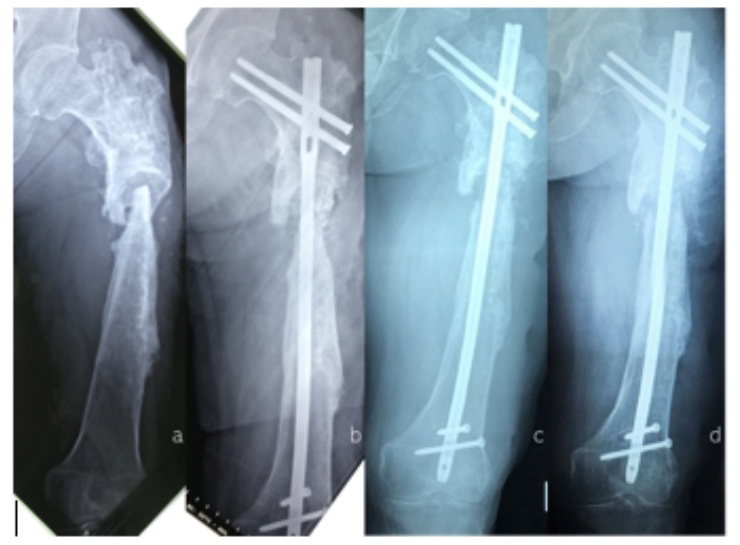

\section{Figure 7}

Radiograph of patient Tas (a) Pre-implantation; (b) Post implantation; (c) 6 months post implantation; (d) 12 months post implantation.

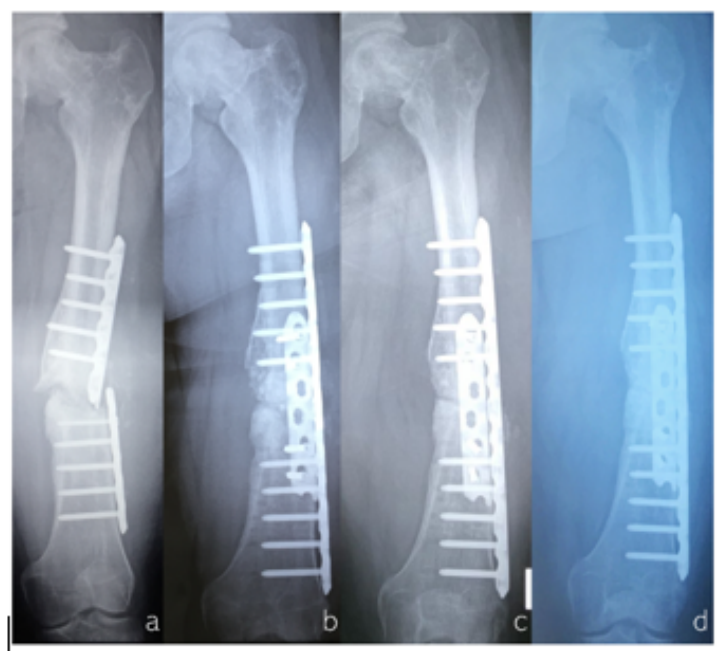

Figure 8 
Radiograph of patient JNe (a) Pre-implantation; (b) Post implantation; (c) 6 months post implantation; (d) 12 months post implantation 